\title{
Does Amnesty Programme in Niger Delta have Economic Benefit to Nigeria?
}

\section{Touitou, Tina $\mathbf{C}$}

Department of Mass Communication Babcock University IIishan-Remo Ogun State, Nigeria

\begin{abstract}
The Niger Delta is said to be the world's largest wetland and the fourth largest ethnic group in Nigeria. The oil and gas in that region represents $97 \%$ of Nigeria's foreign exchange earnings and this accounts for a major chunk of the wealth of the country. The region has for some years been the site of major confrontations between the people and the Nigerian government's security forces, resulting in extrajudicial executions, arbitrary detentions, and draconian restrictions on the rights to freedom of expression, association, and assembly. To proffer solution, Federal government came up with Postamnesty Programme. Based on this, the study sought to: (i) determine the economic benefits of Postamnesty Progromme to Nigeria. (ii) Determine the level of effectiveness of the implementation of the Post Amnesty Progrmme since its inception in 2009. The research design was descriptive survey method. The population of the study was 4,798,519 million youths [15-39years][last Census2006] in Delta State, Bayelsa State and Rivers State. The study made use of qualitative and quantitative data analyses. The sample size was 400 using Taro Yamane formula. Purposive sampling technique was used to select the respondents in each of the states. A pilot study was conducted using split-half method and tested with Spearman Brown. Validity of instruments was measured using content validity .The OneSample Kolmogorv-Smirnov $(Z)$ test is used in testing the hypothesis: Amnesty programme does not have economic benefits to the Nigeria. $\left(Z_{\text {cal }}=4.930>Z_{\text {critical }}=1.96, p<0.05\right)$. This result is significant as p-value of $0.00<0.05$. Thus, the null hypothesis is rejected and the alternative hypothesis accepted accordingly. Hence, Amnesty programme does have economic benefits to Nigeria. It concluded that is only in peaceful regions that meaningful collaboration and developments can take place, as well as investment and development. Where its recommendation is for the Federal government to engage in equitable distribution of resources in the country and elimination of bureaucracy such as: corruption, dehumanization, marginalization, and underdevelopment and deprivation.
\end{abstract}

Keywords: Niger Delta, Amnesty, Public relations, Militant, Benefit.

\section{Introduction}

The Niger Delta crisis has been going on for decades but it has only just deteriorated to its present stage of militancy, killings, kidnappings and the likes. The effects of oil in the fragile Niger Delta communities and environment have been enormous. $85 \%$ of national oil revenues end up in the hands of $1 \%$ of the population, while local indigenous people have seen little if any improvement in their standard of living while suffering serious damage to their natural environment.[http://klkntv.cm/Global/Story.asp].

The UNDP (2009) describes the region as suffering from "administrative neglect, crumbling social infrastructure and services, high unemployment, social deprivation, abject poverty, filth and squalor and endemic conflict." The majority of the people of the Niger Delta do not have adequate access to clean water or health care. Their poverty and its contrast with the wealth generated by oil has become one of the world's starkest and most disturbing examples of the "resource curse". UNDP (2009) further to say that under Nigerian law, local communities have no legal rights to oil and gas reserves in their territory. The Federal Government allocates permits, licenses and leases to survey, prospect for and extract oil to the oil companies, who are then automatically granted access to the land covered by their permit, lease or license. The fact that the people of the Niger Delta have not benefited from oil wealth is only part of the story. Widespread and unchecked human rights violations related to the oil industry have pushed many people deeper into poverty and deprivation, fuelled conflict and led to a pervasive sense of powerlessness and frustration. The multi-dimensional crisis is driven by the actions of the security forces and militant groups, extensive pollution of land and water, corruption, corporate failures, bad practices and serious government neglect. Much of the population in the oil producing areas of the Delta relies on fisheries, subsistent agriculture and associated processing industries for their livelihood. Oil spills, waste dumping and gas flaring [gas is separated from oil in Nigeria, most of it is burnt as waste, these practices are endemic in the Niger Delta. This pollution, which has affected the area for decades, has damaged the soil, water and air quality. Hundreds of thousands of people are affected, particularly the poorest and those who rely on traditional livelihoods such as fishing and agriculture, (UNDP, 2009). Widespread environmental damage associated with oil extraction has destroyed livelihoods, polluted water and undermined health, and even basic services, such as water and 
sanitation are lacking in many areas. Many of the development initiatives that have been established have been marred by corruption and bad planning, leaving behind a trail of half-finished or non-functioning projects. This situation is often accompanied with massive socio-economic disorganization, lawlessness, loss of lives and the general belief that government is incapable of correctly handling the situation, [http://klkntv.cm/Global/Story.asp].

In 2008, Nigeria government and private initiatives sought for lasting solutions to the crisis appointed a committee known as the Ledum Mittee to look into the crisis and come up with recommendations for peace. The Ledum Mittee Technical committee was launched in September $8^{\text {th }} 2008$ with credible members to collate and review all previous reports, memorandum and also to make suggestions to government. The committee then made their research and recommended Amnesty for militant leaders. The Amnesty offer was announced by President Ya'ardua in June 2009. The programme recommends that the region should receive 25\% of the country's revenue which is an improvement on the $13 \%$ revenue they receive.

Presidential panel on Amnesty and Disarmament of Militants in the Niger Delta was also set up to coordinate the Amnesty programme and to advise the government. The Presidential Committee has four sub-committees that are responsible for the development of the area after the militants accepted the Amnesty offer. The committee was also set up to work on the modalities for the involvement of the host communities in the ownership of the Petroleum Assets in Nigeria. The committee further sub-divided the Amnesty programme into the following: the disarmament, rehabilitation and re-integration, oil and gas asset protection, infrastructural development and environmental clean-up and remediation. It is pertinent to note that, how these Post-amnesty Programmes are to be effectively managed and sustained should be the first priority. It should also be noted that the crises in Niger Delta cannot be solved by a single body. There has to be synergy on the path of individual, NGO'S, the government and the multinational oil companies in that region. All of these bodies have to work in union so as to achieve human and community development, and to put an end to militancy and crises in that region.

The Programmes for the Post-amnesty offer includes the following: Disarmament, Rehabilitation and Reintegration, Oil and Gas Asset Protection, Infrastructural Development and Environmental Clean-up, Remediation, skills and acquisition programme for repentant militants, addressing the issue of environmental degradation; construction of an inland water way; construction of a coastal road and provision of good electricity supply. The Amnesty programme is a part of the Federal government determination and desire to put an end to the agitations and violence in the region, with the aim of disarming, rehabilitating and reintegrating militants into their communities as a means to tackle the challenges facing the region. Amnesty programme was a huge success as the militants accepted the offer and began coming out of hiding to hand over their arms and ammunition to the government through the peace committee set up to coordinate the programme. The Post-amnesty period is significant in bringing about lasting peace and development to the region. With the Amnesty declared a success and to be sustained is the efforts and determination of the government to achieve these objectives.

\subsection{Research Question}

1. Does Amnesty programme have economic benefit to Nigeria?

\subsection{Research Hypothesis}

1. Amnesty programme does not have economic benefits to Nigeria

\section{Methodology}

The population of the study comprised of the major stakeholder involved in Niger Delta crisis: Youths aged 1539 years old from the three selected states that include: Bayelsa State, Rivers State and Delta State. These States were chosen based on the fact that they were the most crisis and militancy ridden states in the region. Therefore, the population size of the youths in all the states was 4,798,519 [Based on the last census of 2006]. The sample size was 400 using Taro Yamane formula 1976. The research design employed for this study was descriptive survey design research method. While, stratified random sampling, in order to determine the population quota of each of the States, and purposive sample technique for choosing the actual respondents in each State.

\subsection{Empirical Review of Literature}

Amnesty was defined by Encarta (2009) as an international law and an act of effacing and forgetting past offences granted by the government to person [s] who have been guilty of crime and rebellion against the state. Goldman (2002) is a general pardon of offence by government, a deliberate overlooking of offences against a government. Sabella (2009) sees it as an act of sovereign power designed to apply the principle of "tabula rasa" to past offences usually committed against the state. He noted that the offences which Amnesty generally applies include political depicts, such as treason, sedition or rebellion. The term is applied to rebellious acts against the State. Amnesty differs from pardon in that Amnesty causes the crime to be forgotten, whereas pardon, given after a conviction, exempts the criminal from further punishment. Amnesty is usually granted to a class of criminals or group of persons who may have committed a crime and is offered in order to restore tranquility in the state (Peter, 2004). Some examples of amnesty in United States history were those granted by President Andrew Johnson after the American Civil War and those given to certain wartime offenders after World Wars 1 and 11. Amnesty may be conditioned upon fulfillment of certain obligations within a specified period. In 1974 President Gerald Ford instituted a programme for Vietnam War deserters, and draft evaders requiring them to spend two years doing public service work as the condition for amnesty. Few people took advantage of these terms within the time allowed for the programme (Encarta, 2009).

\subsection{Terms of the Amnesty and its Implications}

Under the Amnesty, all persons that were affected by the Amnesty must surrender and handover their arms to the designated officers, in addition to executing the renunciation of militancy form. It implies that no militant can 
be arrested or killed after their arms have been surrendered and the label "militants" will be removed, and that those who do not surrender their arms and embrace the Amnesty were considered criminals thereafter (Alloy and Festus, 2009)

\subsection{The Beneficiaries of the Amnesty}

President Yar'Adua asserts that the programme is open to all: militants leaders; all militants in the region; all persons that were being prosecuted for the offences related to militant actions, sponsors of the militants, anybody who is directly or indirectly involved in the commission of offences related to the activities of the militants in the region and some civilian prisoners, especially those that had been on death row for a period up to twenty years in the Niger Delta, including suspected rebel leader Henry Okah who is on trial for gun-running and treason. Okah's freedom has been one of the main demands from the Movement for the Emancipation of the Niger Delta [MEND], the country's main militant group.

\subsection{Recovered Arms}

Within the stipulated deadline for the amnesty, about 532 arms, 76 automatic rifles, 21 machine guns, 16 gunboats and 180,000 rounds of ammunition were surrendered. However, about 78,000 AK-47, 230, 000 rounds of ammunition and other sophisticated weapons were believed to still be in the militant's possession [Nigerians in America 2010].

\subsection{Post Amnesty Scheme and the Accomplished Projects}

The Post-amnesty package includes: a presidential pardon, Post-amnesty dialogue, rehabilitation programme, demobilization and reconciliation, re-integration, healing and sustainable development [Modern Ghana News, 2009n.d] A whooping sun of N2.1 trillion was marked for the developmental projects like infrastructural, environmental, human capital development and security programmes, and about N293 billion has been spent on projects like construction of skills acquisition centre, roads and housing units. Parts of the money were also used for environmental upgrading and job provisions (Africa, 2009) and the Federal government to demonstrate its preparedness to ensure successful implementation of the entire Post-amnesty plan. There should be no excuses for non-implementation of the programmes that have been approved to bring an end to arms conflict, wanton destruction of lives and property and other forms of criminality in the Niger Delta region.

The panel will be held responsible for poor execution of the projects which are expected to assist in opening up the Niger Delta region for meaningful development in all areas. The creation of jobs for the large army of restive youths in the region will not only considerably curtail the alarming crime rate in the region, but it will also give such youths a sense of belonging to the Niger Delta region project in particular, and also Nigeria in general. The federal Government cannot afford to pay lip service to all-important Post-amnesty plan.

Failure to implement the programmes sincerely and successfully could make a mess of the relative peace now prevailing in the region. Anything that is capable of eroding the trust and the confidence the ex-militants have in the Federal government pertaining to the Amnesty deal, must be avoided to ensure that the Niger Delta region and other parts of the country continue to enjoy peace and meaningful development. Nigerian Compass suggested that the Federal government should avoid those things that could contributed to the poor execution of vital projects, while implementing the Post-amnesty plan projects specifically geared towards rehabilitating, reintegrating the former militants, as well as the development of infrastructure in Niger Delta. Also, necessary arrangement should be in place to ensure that funds pumped into the projects are judiciously spent and accountability should be the watchword. Armstrong (2000).

\subsection{Benefits of Amnesty Programme}

One of the benefits of Amnesty programme is to enhance youth development in all ramifications. According to Academy Educational Development (2010) Youth development is about people, programmes, institutions and systems that provide all youth "trouble" with the supports and opportunities they need to empower themselves. Pittan [993], defines "Youth development" as the ongoing growth processes in which all youth are engaged in attempting to:

- To meet their basic personal and social needs to be safe, feel cared for, be valued, useful, and be spiritually grounded.

- Build skills and competencies that allows them to function and contribute in their daily lives

- Build capacity of youth to participate effectively in urban poverty reduction through training and by offering employment opportunities in self-employment, formal and informal sectors.

- Enhance youth contribution towards better governance by promoting increase youth participation in local government and matters concerning youth development.

- Provide services aimed at preventing and solving reproductive health problems amongst the youth by provision of information, skills training, education on reproductive health, counseling and referral services.

- Establish mechanisms to effectively communicate and disseminate information to youth, youth organizations and other partners involved in youth work.

- Strengthen youth engagement in the protection and improvement of the environment justice by promoting their participation in environmental justice and governance initiatives

The focus of Amnesty programme policy before adjustment was largely Talent and Human Resource Development, before the focus was shifted to Talent and Human Utilization that include to: provide an overview of community development foundations with reference to institutional roles responsibilities, structure and function; build skills for facilitating community participation and self-mobilization; provide a better understanding of the importance of capacity building of effective community- institutional development; educate and reintegrate and to hold workshops to train and to provide financial assistance to militants. 


\subsection{Strengths of the Amnesty}

Hon. Kinsley Kuku Special Adviser to the President said that before the proclamation of Amnesty for the Niger Delta ex-militants, oil production dropped to an all-time low 700,000 barrels per day. With the initiation of the Post-amnesty programme, production immediately rose to 2.4 million barrels per day. Today, production stands at 2.6 million barrels per day. This means an increase of 1.9 million barrels per day. This means that production savings of crude oil stands at $\$ 104$ million per day for the country.

The Federal Government further consolidated its gains on its post amnesty programme as the United Kingdom Department for International Development [DFID], gave its approval to collaborate in the re-training of Niger Delta ex-militants in community reintegration on completion of their ongoing offshore vocational training. The collaboration between Nigeria and the United Kingdom Department for International Development, is part of the contributions of the international community to bring lasting peace and development to the Niger Delta region in particular and the country as a whole.

\subsection{Summary Strengths of the Amnesty}

- The Amnesty promoted active listening assertive communication and affirming environment for dialogue

- It protected the nation's referent power in the global village

- Circulation of illegal weapons was reduced, if not eliminated

- It promoted reconciliation between the militants and the offended residents who want peace to reign

- The Nigeria government reversed its previously reneged promise on power generation from $6000 \mathrm{MW}$ target by December 2009 to 60,000MW in 2020

- Oil production and output increased as a sharp contrast to the oil dropped in the first quarter of 2009

\subsection{Constraints of the Amnesty}

Aside the strengths of the programme, its goes with constraints which include:

- Health problem for instance, ex-Nigerian President Ya'adua and his sudden departure for Saudi Arabia, which created a power vacuum, this affected the Post-amnesty plans [Nigerians in America 2010].

- The victims of the activities of the militant groups may feel cheated for granting immunity from prosecution through the Amnesty to the militants and consequently have distrusting sentiment about the law, or plan illegal revenge

- There is possibility of impression that criminals may go scot free or crime goes unpunished because pardon will be eventually granted

- Okoko and Peterside (2009) argued that the Amnesty lacks transparency, is inadequately planned and has no clear cut time frame.

- Some militant groups were skeptical about the Amnesty because Dokubo-Asari was arrested in the name of Amnesty

- The legal constraint imposed by the United Nations [UN] on serious crimes seems to limit the boundary of offences that may be amnestied (Priscilla, 2009)

- Ethnic and religious crisis in Jos, Borno and other parts of the nation distracted the government attention. In comparison the study poses that the strengths of Amnesty programme outweigh the constraints

\section{Data Presentation and Analysis}

The data collected through the questionnaire from the youths of the sampled states were presented and discussed descriptively using tables, frequencies and percentages. The Hypothesis was tested using One Sample Kolmogorov-Smirnov $(Z)$ test. This was done with the aid of the Statistical Package for Social Sciences (SPSS) 17.0.

Table-1. Respondents' Feeling about the Amnesty Programme

\begin{tabular}{l|l|l|l|l}
\hline Response & Bayelsa (\%) & Delta (\%) & Rivers (\%) & Total (\%) \\
\hline The programme only enriches the militants & $4(7.7)$ & $8(7.2)$ & $8(8.5)$ & $20(6.5)$ \\
\hline $\begin{array}{l}\text { It is good and welcome development because it brought } \\
\text { peace and sustain peaceful coexistence }\end{array}$ & $30(67.5)$ & $36(32.4)$ & $77(43.9)$ & $145(46.4)$ \\
\hline $\begin{array}{l}\text { The programme will determine the government's } \\
\text { priority on Niger-Delta }\end{array}$ & $5(9.6)$ & $18(16.2)$ & $8(5.4)$ & $31(10.0)$ \\
\hline Indifferent & $1(1.9)$ & $3(2.7)$ & $11(7.5)$ & $15(4.8)$ \\
\hline This programme should go to the right people & $11(21.1)$ & $19(17.1)$ & $28(19.0)$ & $58(18.7)$ \\
\hline Destruction is less and development is enhance & $0(0.0)$ & $22(19.8)$ & $6(4.1)$ & $28(9.0)$ \\
\hline Abolition of indiscriminate killings and dehumanization & $1(1.9)$ & $5(4.5)$ & $8(5.4)$ & $14(4.5)$ \\
\hline Total & $52(100.0)$ & $111(100.0)$ & $147(100.0)$ & $310(100.0)$ \\
\hline
\end{tabular}

Table-2. Amnesty's Usefulness to the Beneficiaries

\begin{tabular}{l|l|l|l|l}
\hline Responses & Bayelsa (\%) & Delta (\%) & Rivers (\%) & Total (\%) \\
\hline It stops kidnapping and killing of human being & $8(15.4)$ & $12(10.8)$ & $10(6.8)$ & $30(9.7)$ \\
\hline It brought peace and security & $31(53.8)$ & $76(88.4)$ & $67(55.9)$ & $189(61.0)$ \\
\hline It is useful to me based on educational benefits & $12(23.1)$ & $10(9.0)$ & $19(12.9)$ & $41(13.2)$ \\
\hline Empowerment & $1(1.9)$ & $13(11.7)$ & $36(24.5)$ & $50(16.1)$ \\
\hline Total & $52(100.0)$ & $111(100.0)$ & $147(100.0)$ & $310(100.0)$ \\
\hline Source: Field Survey
\end{tabular}

Source: Field Survey, 2015 
When asked how amnesty was useful to them as beneficiaries, Table 2 reveals that majority of the respondents (61\%) said it brought peace and security. Other benefits pointed out by the respondents included empowerment ( $16.1 \%$ responses), educational benefits (13.2\% responses) and eradication of kidnapping and killings of human beings $(9.7 \%)$.

Table-3. There is Relative Peace in the Niger-Delta Region as a Result of the Amnesty

\begin{tabular}{l|l|l|l|l|l|l}
\hline State & Agree (\%) & Strong Agree (\%) & Indifferent (\%) & Disagree (\%) & Strongly Disagree (\%) & Total (\%) \\
\hline Bayelsa & $16(30.8)$ & $18(34.6)$ & $4(7.7)$ & $6(11.5)$ & $8(15.4)$ & $52(100.0)$ \\
\hline Delta & $74(66.7)$ & $12(10.8)$ & $10(9.0)$ & $12(10.8)$ & $7(6.3)$ & $111(100.0)$ \\
\hline Rivers & $52(35.4)$ & $32(21.8)$ & $21(14.3)$ & $28(19)$ & $14(9.5)$ & $147(100.0)$ \\
\hline Total & $142(45.8)$ & $62(20.0)$ & $35(11.3)$ & $42(13.5)$ & $29(9.4)$ & $310(100.0)$ \\
\hline
\end{tabular}

Source: Field Survey, 2015

In response to question Table 3 reveals that 142 respondents (45.8\%) and 62 respondents $(20 \%), 35$ respondents (11.3\%), 42 respondents (13.5\%) and 29 respondents $(9.4 \%)$ agreed and strongly agreed, indifferent, disagreed and strongly disagreed respectively, that there is relative peace in the Niger-Delta region as a result of the Amnesty. This is the view of the respondents from the various sampled Niger-Delta states. Therefore, the study proves that there is relative peace in the Niger Delta region as a result of the Amnesty.

Table-4. The Nigerian Image is boosted as a Result of the Peace Brought about by Amnesty

\begin{tabular}{l|l|l|l|l|l|l}
\hline State & Agree (\%) & Strong Agree (\%) & Indifferent (\%) & Disagree (\%) & Strongly Disagree (\%) & Total (\%) \\
\hline Bayelsa & $21(40.4)$ & $21(40.4)$ & $4(7.7)$ & $6(11.5)$ & 0 & $52(100.0)$ \\
\hline Delta & $68(61.3)$ & $23(20.7)$ & $3(2.7)$ & $12(10.8)$ & $5(4.5)$ & $111(100.0)$ \\
\hline Rivers & $62(42.2)$ & $38(25.9)$ & $20(13.6)$ & $15(10.2)$ & $12(8.2)$ & $147(100.0)$ \\
\hline Total & $151(48.7)$ & $82(26.5)$ & $27(8.7)$ & $33(10.6)$ & $17(5.5)$ & $310(100.0)$ \\
\hline
\end{tabular}

Table 4 reveals that 151 respondents $(48.7 \%)$ and 82 respondents (26.5\%), 27 respondents (8.7\%) 33 respondents (10.6\%), 17 respondents (5.5\%) agreed, strongly agreed, indifferent, disagreed and strongly disagreed respectively, that the Nigerian image is boosted as a result of the peace brought about by the Amnesty programme. This is also true in each of the sampled Niger-Delta states as their individual responses concur with this. As regards to the study, Nigerian image is boosted as a result of the peace brought about by the Amnesty programme.

Table-5. The Economic Benefit of Amnesty to the Country

\begin{tabular}{l|l|l|l|l}
\hline Response & Bayelsa (\%) & Delta (\%) & Rivers (\%) & Total (\%) \\
\hline $\begin{array}{l}\text { Increased revenue, high level of productivity and } \\
\text { investment opportunities }\end{array}$ & $28(53.7)$ & $24(21.6)$ & $42(28.1)$ & $94(30.3)$ \\
\hline None; it is a sheer waste of funds and resources & $3(5.7)$ & $29(26.1)$ & $30(20.4)$ & $62(19.9)$ \\
\hline $\begin{array}{l}\text { Human resource development and socio-economic } \\
\text { independence and stability }\end{array}$ & $10(19.2)$ & $34(30.6)$ & $36(24.4)$ & $80(25.9)$ \\
\hline Reduction of vandalisation & $2(3.8)$ & $12(10.8)$ & $5(3.4)$ & $19(6.1)$ \\
\hline Conducive environment & $4(7.7)$ & $4(3.6)$ & $8(5.4)$ & $16(5.2)$ \\
\hline Youth empowerment & $5(9.6)$ & $8(7.2)$ & $26(17.7)$ & $39(12.6)$ \\
\hline Total & $52(100.0)$ & $111(100.0)$ & $147(100.0)$ & $310(100.0)$ \\
\hline Source: Field Survey, 2015 & & &
\end{tabular}

Table 5 shows the views of the respondents on what they perceived to be the economic benefits of Amnesty to the country. $30.3 \%$ of the respondents noted that it increased revenue, high level of productivity and investment opportunities. While, $25.9 \%$ noted that it increased human resource development, socio-economic independence and stability. There were other economic benefits pointed out by the respondents, as presented in table 4.14. However, it is worthy of note that 62 respondents $(19.9 \%)$ said that there was no economic benefit of Amnesty to the country and that it was a waste of resources. Out of this 62 persons, 29 of them were from Delta State while 30 of them were from Rivers state. This reveals that more of the respondents from Delta and Rivers states were disgruntled towards the Amnesty programme than respondents from Bayelsa State.

\section{Test of Hypothesis}

\subsection{Amnesty Programme does not have Economic Benefits to the Country}

The data presented in Table 5 is used in testing this hypothesis. The One-Sample Kolmogorv-Smirnov $(Z)$ test is used in testing this hypothesis.

As presented in Table 5 the calculated Z-value is 4.930. This is less than the critical Z-value of 1.96 (at $95 \%$ level of significance) i.e. $Z_{\text {calculated }}(4.930)>Z_{\text {critical }}(1.96)$. This result is significant as $p$-value of $0.00<0.05$. Thus, the null hypothesis is rejected and the alternative hypothesis accepted accordingly. Hence, Amnesty programme does have economic benefits to the country.

\subsubsection{Findings of the Study}

The study also exposes the gains accrued as a result of Amnesty, as well as the inability of the Federal government to fulfill its promises in Niger Delta region. It also sheds light on the fact that the programme only enriches the militants rather than being channeled to the entire youths of the Niger Delta. The study further reveals that most of the real militants are still in the creeks demanding to be amnestied. It further reveals that most of the youths who acquired arms and ammunitions during the Governor Odili political campaign were the so-called 
militants that laid down arms and are presently enjoying the amnesty initiative. Much as this programme would be acknowledged as succeeding, it is still pertinent to know that many of the ex-militants are rendered idle and jobless in their communities, after the two weeks rehabilitation programme. Many of whom were promised to be sent and trained abroad or in school presently have their dreams shattered owing to lack of monitoring or proper integration into the society. Therefore, the Federal government should muster the political will to extend the term of Amnesty to include those seeking to be amnestied, to sustain the relative peace and benefits the Amnesty programme brought to the region.

\subsubsection{Summary of the Findings}

- Amnesty programme has significant economic benefits to the country. The calculated Z-value is 4.930. This is less than the critical $\mathrm{Z}$-value of 1.96 (at $95 \%$ level of significance) i.e. $Z_{\text {calculated }}(4.930)>Z_{\text {critical }}$ (1.96). This result is significant as p-value of $0.00<0.05$. Thus, the null hypothesis is rejected and the alternative hypothesis accepted.

- The example of the benefits derived as result of Amnesty include: youth empowerment, reduction of vandalisation, human resource development and socio-economic independence and stability, increased revenue in the oil and gas sector, creation of Niger Delta Affairs, high level of productivity, reduction of knapping and sea piracy and increased investment opportunities etc.

- There is political interest in the Niger-Delta crisis, in that the Amnesty programme that is meant for the entire Niger Delta youths is now being targeted at a handful who has "god fathers."

- The nation's economy which depends largely on oil output has regained stability

- 5,067 of the amnesty beneficiaries had already graduated in skills acquisition fields such as welding and fabrication [1,847], entrepreneurship[1,609], pipe fitting [150], carpentry and plumbing[206], oil drilling [32], electrical installation [232], ICT [125], marine related courses [567] and others [302], while, 95 have been offered direct employment in various governmental and private establishments [Field Survey 2015]

\section{Conclusion}

There is not a single person or organization that would not want to experience peace, even warmongers. This study on the Amnesty programme is synonymous with peace. The essence of the Amnesty programme in the Niger Delta is to bring about lasting peace to the troubled region. To this are tied some benefits. It is only in peaceful regions that meaningful collaboration and developments can take place. Where there is investment and development, there is influx of income, thus earnings increase and socio-economic development programmes abound, which goes a long way in ensuring the safety and the reduction of societal vices. The cycle goes on. These are all as a result of the realization of peace; via the successful implementation and sustainability of the Amnesty programme. In the realization and sustainability of the Amnesty progromme, there is need to reflect on the Section 44 [3] of the constitution of the Federal Republic of Nigeria and other enactments which vest the entire control and management of oil and gas in Nigeria on the Federal government. This section of the constitution should be reviewed in favor of regional ownership of petroleum as practiced in USA and Canada. Constitutional power for the management and control of petroleum must be shared with all arms of government. And also the petroleum policy should be made to reflect how Nigeria can develop its petroleum resources in such a way that all Nigerians will benefit, in order to maintain and sustain the Post-amnesty peace agreement in the region. These will ensure that the gains accrued as a result of Amnesty such as: youth empowerment, reduction of vandalization, human resource development and socio-economic independence and stability, increased revenue in the oil and gas sector, creation of Niger Delta Affairs Ministry, high level of productivity and investment opportunities would be sustained Hence it is very safe to conclude that Amnesty does have economic benefits to the country.

\section{Recommendations}

The benefits accrued as a result of Amnesty programme need to be properly sustained and maintained through the effective evaluation and assessments framework. If they are not embraced in managing Post-amnesty Programme, the implications should mean that Post-amnesty Programme would not sustain the Niger Delta peace agreement [treaties] beyond its time- frame. Also Post-amnesty Programme would be a waste of money, time and human resources and would not bring lasting solution in the region.

Secondly, if the Post-amnesty Programme is not properly evaluated as to see whether the relative peace being enjoyed in the region now is the result of Amnesty programme or a result of President Goodluck Ebele being in power, the implication is that there would be more devastation in the region and in the country as a whole after the President's regime.

Therefore, it is expedient for the Federal government to engage in equitable distribution of resources in the country and elimination of bureaucracy such as: corruption, dehumanization, marginalization, and underdevelopment and deprivation. And to ensure that the Niger Delta youths are gainfully employed and developed. Anything different from this will render the efforts invested in Post-amnesty Programme a sheer waste. The issue of management of petroleum resources, if not properly handled could lead to greater devastation, political and civil unrest in the Niger Delta.

\section{References}

Academy Educational Development, 2010. Agriculture and Achieving the Millennium Development Goals.

Africa, 2009. Nigeria: Niger Delta- carrying new developmental roadmap. Available from www.allAfrica.com [Accessed 1/2/10].

Alloy, O.W. and E. Festus, 2009. Amnesty to militants sparks off controversy. Facts Express, 1(4): 6-11.

Armstrong, M., 2000. Strategic human resource management: A guide to action. 2nd Edn., London: Kogan Page.

Encarta, 2009. Available from http://en.wikipedia.org/wiki/movement [Accessed February 7, 2008].

Goldman, 2002. Available from http://en.wikipedia.org/wiki/movement_for_the_Survival_of_the_Ogoni_People.

Okoko and A. Peterside, 2009. Available from http://www.nigeriancuriosity.com/2009/09/Nger-Delta-Amnesty-Dividend2009. 
Peter, P., 2004. Inequality and social conflict over land. Journal of Agrarian Change, Detselig Enterprise Ltd., Calgary, 4(3): 269-3 14.

Priscilla, H., 2009. Negotiating justice: Guidance for mediators. February 2009 Report Centre for Humanitarian Dialogue(HD Centre). Available from www.hdcentre.com.

Sabella, 2009. Amnesty body blames government, militants for Niger Delta woes.

UNDP, 2009. Human development report. 2009. New York: Oxford University Press.

\section{Bibliography}

Abrifor, C.A., 2008. The Niger Delta region: A conflict of ethnic nationalities and violence. Nigeria: Harey Publications Company.

Adebayo, S.N., 2005. The golden path to conflict prevention and resolution. Ibadan: Faith Conflict Loud Books.

Adu, 2005. Available from jobopportunitiesinthenigerdelt.

Africa, 2010. Nigeria: Niger Delta- carrying new developmental roadmap Available from www.allAfrica.com [Accessed 1/2/10].

Akpenpuun, D., 2006. Prevention and management. Ibadan: CentrePublications Publishers.

Albert, 2001 . Available from https://jeffmiller.house.gov/.

Allafrica.com, 2002. Shell records 262 oil spills. Available from http://allafrica.com/stories/200303060433.html [Accessed June, 20, 2007].

Alloy, O.W. and E. Festus, 2009. Amnesty to militants sparks off controversy. Facts Express, 1(4): 6-11.

Federal Office of Statistics, 1999. Poverty profile for Nigeria 1980-1999. Nigeria: FOS Publication.

Folarin, 2002. Cited in Anaeto et. al. 2008. Models and theories of communication. USA: African Renaissance Books Incorporated.

Smith, 2011. Available from www.allAfrica.com $[$ Accessed 1/2/10 $]$.

United Ijaw States, 2007. Corruption in high places. Available from http://www.unitedijawstates.comaccessed [Accessed June 27, 2007].

United Nations Development Porgramme, 2006. Niger Delta Human Development Report Abuja: UNDP.

White, E.G., 1995. Education -Learning from the Master Teacher. Canada: Pacific Press Publishing Association Oshawa.

Wikipedia, 2010. Nigeria. Available from www.wikipedia.org.

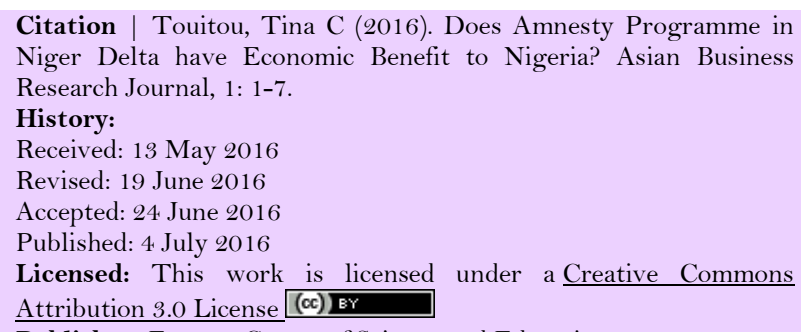

Citation | Touitou, Tina C (2016). Does Amnesty Programme in Niger Delta have Economic Benefit to Nigeria? Asian Business Research Journal, 1: 1-7.

History:

Received: 13 May 2016

Revised: 19 June 2016

Accepted: 24 June 2016

Published: 4 July 2016

Licensed: This work is licensed under a Creative Commons

Attribution 3.0 License (cc)) Er

Publisher: Eastern Centre of Science and Education

Eastern Centre of Science and Education is not responsible or answerable for any loss, damage or liability, etc. caused in relation to/arising out of the use

of the content. Any queries should be directed to the corresponding author of the article.

Funding: This study received no specific financial support.

Competing Interests: The author declares that there are no conflicts of interests regarding the publication of this paper.

Transparency: The author confirms that the manuscript is an honest, accurate, and transparent account of the study was reported; that no vital features of the study have been omitted; and that any discrepancies from the study as planned have been explained.

Ethical: This study follows all ethical practices during writing. 